\title{
Effect of recycle on treatment of aircraft de-icing fluid in an anaerobic baffled reactor
}

\author{
Kevin Kennedy* and Micha Barriault \\ Dept. of Civil Engineering, 161 Louis Pasteur, University of Ottawa, Ottawa Canada, K1N 6N5
}

\begin{abstract}
Aircraft de-icing fluid at $7000 \mathrm{mg} \mathrm{COD} / \ell$ was successfully treated in an anaerobic baffled reactor operated with and without recycle at volumetric organic loading rate of between 4 and $11 \mathrm{~g} \mathrm{COD} / \ell_{\text {reactor }} \cdot d$. Reactor recycle was found to improve reactor performance. The anaerobic baffled reactor operated with a 6:1 recycle ratio achieved a minimum hydraulic retention time of $17 \mathrm{~h}$ with an acceptable COD removal efficiency of $93 \%$ at a volumetric organic loading rate of $9.9 \mathrm{~g} \mathrm{COD} / \ell_{\text {reactor }} \cdot \mathrm{d}$.

This corresponded to a specific organic loading rate of $0.35 \mathrm{~g}$ COD/g VSS $\mathrm{d}$ and specific organic removal rate of $0.32 \mathrm{~g}$ $\mathrm{COD}_{\mathrm{rem}} / \mathrm{g}$ VSS·d. Without recycle similar removal efficiency was achieved; however, the loading rates were about $40 \%$ less. Due to biomass growth specific organic loading rate was not found to vary significantly through most of the experimental period despite loading rate increases.

Hydrodynamically, an anaerobic baffled reactor may be characterised as an in-series continuously stirred tank reactor where the number of continuously stirred tank reactors corresponded to the number of actual compartments. Volatile fatty acid profiles tend to indicate that anaerobic baffled reactor compartmentalisation served to separate acidogenic and methanogenic activities longitudinally through the reactor, with the highest proportion of acidogenic activity in the first compartments. The net accumulated yield within the anaerobic baffled reactor was found to be of $0.007 \mathrm{~g} \mathrm{VSS} / \mathrm{g} \mathrm{COD}_{\text {rem }}$ when the $\mathrm{ABR}$ was operated without recycle and of $0.016 \mathrm{~g} \mathrm{VSS} / \mathrm{g} \mathrm{COD}$ rem for the $\mathrm{ABR}$ operated with recycle.
\end{abstract}

Keywords: anaerobic baffled reactor, de-icing fluid, treatment

\section{Nomenclature}

ABR $=$ anaerobic baffled reactors
ADF $=$ aircraft de-icing fluid
COD $=$ chemical oxygen demand
CSTR $=$ continuously stirred tank reactor
HRT $=$ hydraulic retention time
ID $=$ internal diameter
OLR $=$ volumetric organic loading rate
RTD $=$ residence time distribution
SOLR $=$ specific organic loading rate
SORR $=$ specific organic removal rate
SRT $=$ solids retention time
SS $=$ steady state
STP $=$ standard temperature and pressure
TSS $=$ total suspended solids
UASB $=$ upflow anaerobic sludge blanket
VFA $=$ volatile fatty acids
VSS $=$ volatile suspended solids

\section{Introduction}

Successful treatment of ADF has already been achieved using high-rate anaerobic reactors. Albany International Airport (Albany, NY), achieved 95\% removal efficiencies for propylene glycol based ADF using a $700 \ell$ anaerobic fluidised bed reactor (Switzenbaum et al., 2001) at an OLR of $15 \mathrm{~kg} \mathrm{COD} /$ $\mathrm{m}^{3}{ }_{\text {reactor }} \cdot \mathrm{d}$. However, high fluidisation costs limited this tech-

\footnotetext{
* To whom all correspondence should be addressed.

政 +91613 562-5800 (ext 6133); fax: +91 6135625173 ;

e-mail: kkennedy@uottawa.ca

Received 7 December 2004; accepted in revised form 20 April 2005.
}

nology. Mulligan et al. (1997) successfully treated 90\% COD removal of ethylene glycol based ADF in an anaerobic multiplate reactor at an OLR of $16.5 \mathrm{~kg} \mathrm{COD} / \mathrm{m}^{3}{ }_{\text {reactor }} \cdot \mathrm{d}$. However, the complex multi-plate arrangement resulted in high capital costs as well as operational problems. Darlington and Kennedy (1998) and Pham and Kennedy (2004) reported treatment of ethylene glycol-based ADF wastewaters (5 to $20 \mathrm{~g}$ $\mathrm{COD} / \ell$ ) using UASB reactors. At an OLR up to $38.7 \mathrm{~kg} \mathrm{COD/}$ $\mathrm{m}^{3} \mathrm{~d}$, COD removal efficiencies ranged between 70 to $98 \%$. Although treatment of ADF by UASB reactors proved to be successful, treatment was limited by the maximum flow rate attainable before washout of biomass occurred. At high OLR, excess biogas production increased solids loss as gas bubbles attached themselves to the anaerobic biomass and failed to detach before the granules were entrained into the effluent line. The simple design and particular flow characteristics within an ABR which lead to long SRT may overcome the inherent problems associated with treatment of ADF in other highrate anaerobic reactors (Tilche and Yang, 1987; Grobicki and Stuckey, 1991; Barber and Stuckey, 1999).

The ABR (Fig. 1) has no moving parts and merely uses a series of baffles to force the wastewater to flow over and then under them as it travels through the reactor and creates conditions approaching plug flow (Bachman et al., 1985). Bacteria within the reactor may rise, and then settle within the reactor due to gas production and flow characteristics, yet their movement through the reactor occurs at a very slow rate, thus producing long SRT. Furthermore, the compartmentalisation of the bacteria may provide the ability to separate acidogenesis and methanogenesis longitudinally down the reactor, allowing the different bacterial groups to operate at their preferred conditions (i.e. pH, Barber and Stuckey, 1999). It is believed that the use of granular sludge will enhance the inherent advantages of ABRs described by Barber and Stuckey (1999). 


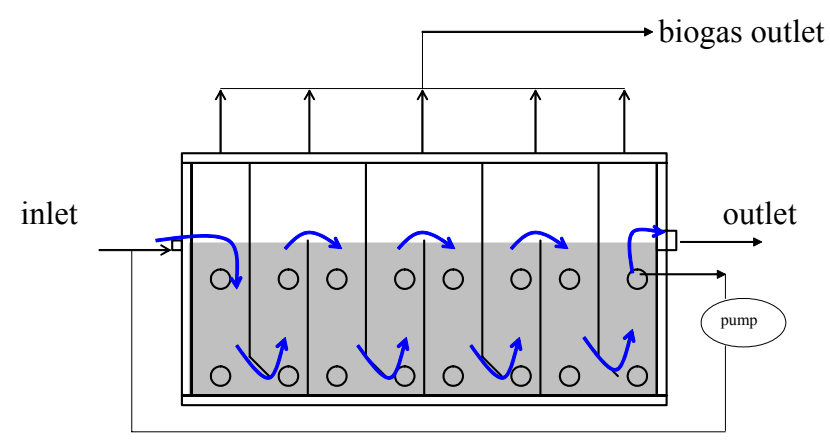

Figure 1

Schematic of an ABR (recycle) showing liquid flow and sampling ports

Boopathy and Tilche (1991) treated molasses wastewater in an ABR with granular biomass and reported that the improved settling characteristics of granular sludge (compared to bioflocs) increased the SRT and produced an effluent that was lower in suspended solids. Hutñan et al. (1999) reported on the methanogenic and non-methanogenic activity of granulated biomass in a four compartment ABR as compared to a UASB reactor. The authors found that the ABR had maximum specific hydrolytic and acidogenic activities that were 10 to 25 times and specific methanogenic activity 2 times higher than the UASB reactor. Results demonstrated that compartmentalisation of the ABR allowed the different bacterial groups to flourish in their preferred conditions. Hutňan et al. (1999) also observed that the specific hydrolytic and acidogenic activities were the highest in the first compartment while these activities remained almost constant in other compartments

In general, ABR recycle should reduce treatment efficiency because it results in the system moving away from plug flow towards completely mixed conditions, and as such the mass transfer driving force for substrate removal is reduced. However, Chynoweth et al. (1980) found that $20 \%$ effluent recycle had a positive effect on methane yield (increase of $30 \%$ ) over control reactors. They also found that the addition of a recycle stream alleviated the problems of low $\mathrm{pH}$ caused by high levels of VFA at the front of the reactor, and discouraged gelatinous bacterial growth at the reactor inlet for the treatment of complex protein carbohydrate wastewater (Bachmann et al., 1983). Recycle was also reported to benefit the ABR through dilution of toxicants in the influent (Bachmann et al., 1985; Grobicki and Stuckey, 1991). On the other hand Grobicki and Stuckey (1992) and Nachaiyasit (1995) noted that with non-granular biomass, recycle had a negative effect caused by increased mixing which encouraged solids loss, and disrupted symbiotic relationships (Henze and Harremoës, 1983). The overall benefits of recycle are unclear and it is believed that the ultimate use of recycle in an ABR will depend on the type of waste being treated (Barber and Stuckey, 1999) and the type of biomass that is used.

Since ADF waste has inherent toxicity (Pham, 2002) the following research focused on the effect of recycle on the application of ABR for treatment of $1 \%(\mathrm{v} / \mathrm{v})$ ADF. Additionally mixing studies were conducted to see if the ABR may be characterised as CSTRs-in-series where the number of CSTRs, corresponded to the number of actual reactor compartments.

\section{Materials and methods}

Two Plexiglas ${ }^{\mathrm{TM}}$ bench-scale ABRs $(300 \times 600 \times 250 \mathrm{~mm} ; \mathrm{h} \times 1 \times \mathrm{w})$ were constructed with four compartments and a liquid operating level of $200 \mathrm{~mm}$ to give a working volume of $7.7 \ell$ per compart- ment (Fig. 1). Each compartment comprised a downflow section and an upflow section each $75 \mathrm{~mm}$ wide that were delineated by a vertical baffle coming down from the top of the reactor and terminating with a $45^{\circ}$ angled portion which was used to promote mixing within the upflow section of the compartment. Both reactors were inoculated with $10 \ell$ of anaerobic granular biomass (distributed evenly between the 4 compartments i.e. $2.5 \mathrm{l} /$ compartment.) obtained from a chemical thermal mechanical pulp UASB treatment plant. It is common working practice to use granular sludge from one facility to inoculate new plants. Although both ABRs were equipped with an internal recycle set at a 6:1 recycle to feed ratio, only one reactor was operated with recycle, where the other was operated without.

Feed maintained at $4^{\circ} \mathrm{C}$ was fed continuously to the ABRs which were maintained at $34 \pm 2^{\circ} \mathrm{C}$ in a temperature-controlled room. All experiments were conducted with ethylene glycolbased UCAR XL 54 ADF diluted to $1 \%$ by volume to give a concentration of $7000 \mathrm{mg} \mathrm{COD} / \ell$. Nutrients and buffering capacity were added as shown in Table 2 . The feed concentration was chosen based on Pham (2002) who reported that 1.2\% XL 54 ADF exhibited biomass toxicity but a concentration of $1 \% \mathrm{XL}$ $54 \mathrm{ADF}$ was not inhibitory to granular anaerobic biomass. Figure 1 shows the flow of ADF through the reactor. Recycle was drawn from the top sample port in the final upflow section and returned with the influent line using a peristaltic pump. Effluent exited through the outlet port and flowed to a U-tube which served to maintain the anaerobic conditions within the ABR. Biogas was channelled though the gas collection manifold to a wet tip gas meters for volume measurement. Liquid and solid samples required for the various analytical tests were collected through sample ports located at the top and bottom portions of each of the upflow and downflow sections of the compartments (Fig. 1).

Hydrodynamic characteristics of the ABR were determined by a step tracer study prior to the biological phase of testing. A water-filled ABR water was operated without recycle at anticipated HRTs of $36 \mathrm{~h}, 6 \mathrm{~h}$ and $1 \mathrm{~h}$. Feed water was then replaced with a dilute solution of Rhodamine (step change tracer) which was monitored with time at the outlet using a fluorometer. The output $\mathbf{F}$ curve (dimensionless form of the effluent concentration curve) from a series of $N$ ideal CSTR in series can be described by the following equation (Levenspiel, 1999):

$$
\mathbf{F}=1-e^{-N \theta}\left[1+N \theta+\frac{(N \theta)^{2}}{2 !}+\ldots+\frac{(N \theta)^{N-1}}{(N-1) !}+\ldots\right]
$$

Where dimensionless value of concentration $(\mathbf{F})$ and time $(\theta)$ is given by:

$$
\begin{aligned}
& \mathbf{F}=\frac{C_{t}}{C_{\text {tracer }}} \\
& \theta=\frac{t}{H R T}
\end{aligned}
$$

where:

$$
\begin{aligned}
& N=\text { number of ideal CSTR in series } \\
& \mathrm{C}_{\mathrm{t}}=\text { outlet tracer concentration at time } \mathrm{t} \\
& \mathrm{C}_{\text {tracer }}=\text { step input tracer concentration } \\
& \mathrm{t}^{\text {tracer }}=\text { time since the step tracer input } \\
& \text { HRT }=\text { hydraulic retention time. }
\end{aligned}
$$

Experimentally determined $\mathbf{F}$ curves were compared to theoretical CSTR in series $\mathbf{F}$ curves using residual sum of squares (Eq. (4) to determine whether or not the CSTR in series model could accurately describe the ABR. If the CSTR-in-series model could be held as valid, soluble samples taken from a single sam- 
pling location could be considered to represent the entire compartment.

$$
R^{2}=\frac{R S S_{c f m}}{T S S_{c f m}}=\frac{\sum_{i=1}^{n}\left(\hat{y}_{i}-\bar{y}\right)^{2}}{\sum_{i=1}^{n}\left(y_{i}-\bar{y}\right)^{2}}
$$

where:

$$
\begin{aligned}
\mathrm{RSS}_{\text {cfm }}= & \text { residual sum of squares corrected for the mean } \\
\mathrm{TSS}_{\text {cfm }}= & \text { total sum of squares corrected for the mean } \\
\bar{y}= & \text { average value of y (in this case } \mathbf{F} \text { from the } \\
& \text { mixing study) } \\
\hat{y}= & \text { value predicted by the model } \\
\mathrm{y}_{\mathrm{i}}= & \text { value of y obtained experimentally } \\
\mathrm{R}^{2}= & \text { proportion of variation about the average } \\
& \text { explained by the model }
\end{aligned}
$$

Following inoculation, the two ABRs (with and without recycle) were initially run at a long HRT followed by stepwise reduction in HRT to acclimate the biomass (Barber and Stuckey, 1999) to ADF. In the acclimation phase, both ABRs were set to recycle and the flow rate was ramped up over a four- week period from an initial HRT of $80 \mathrm{~h}$ to their respective first SS HRT (39 h without recycle and $36 \mathrm{~h}$ with recycle). ABRs were considered to be at SS when the outlet VFA concentrations remained constant $( \pm 10 \%)$ for three consecutive days. Each SS condition was maintained for no less than 3 HRTs. In the case of an HRT of less than one day, the reactors were maintained at SS for three consecutive days before increasing the feed rate (decreasing the HRT). At SS, COD and VFA samples were taken from the port at the top of the upflow section of each compartment to create reactor compartment profiles. Suspended solid content of the effluent was monitored daily. Table 1 summarises the SS HRT and OLRs evaluated.

Biomass samples were taken from each compartment of each reactor at the end of the run period for determination of settling characteristics. Results were compared to those of the seed sludge. Biomass settling velocities were determined based on the procedure described by Andras et al. (1989). Briefly, a $7 \mathrm{~m} \ell$ biomass sample was placed in a glass upflow velocity test tube (length $=200 \mathrm{~mm}$; ID. $=19 \mathrm{~mm}$ ). Water at $35^{\circ} \mathrm{C}$ was pumped through the tube for $5 \mathrm{~min}$ at successively increasing flow rates. The fractions of biomass overflowing from the tube were collected on Whatman ${ }^{\circledR} 185 \mathrm{~mm}$ diameter, Grade 1 filter papers $(11 \mu \mathrm{m}$ pore size) and settling curves were determined by plotting the cumulative TSS washout against upflow velocity. The $v_{50}$, settling velocity for the granular biomass, was considered to be the velocity at which $50 \%$ of the biomass washed out.

Samples for COD determination were centrifuged for $10 \mathrm{~min}$ at $10000 \mathrm{r} / \mathrm{min}$ and the supernatant was drawn off to determine soluble COD using the closed reflux colorimetric technique (Standard Methods, 1985). A Perkin-Elmer spectrophotometer was used to measure light absorbance at $600 \mathrm{~nm}$ of the prepared COD samples. COD tests were performed in duplicate.

VFA samples were centrifuged at $5000 \mathrm{r} / \mathrm{min}$ for $2 \mathrm{~min}$ in a micro-centrifuge, and the supernatant was diluted with an equal

\begin{tabular}{|c|c|c|}
\hline \multicolumn{3}{|c|}{$\begin{array}{c}\text { TABLE } 1 \\
\text { Summary of SS conditions tested }\end{array}$} \\
\hline ABR & $\begin{array}{c}\text { HRT } \\
\text { (h) }\end{array}$ & $\begin{array}{c}\text { OLR } \\
\left(\mathrm{g} \text { COD } / \ell_{\text {reactor }} \cdot \mathrm{d}\right)\end{array}$ \\
\hline \multirow[t]{3}{*}{ without recycle } & 39 & 4.3 \\
\hline & 27 & 6.2 \\
\hline & 20 & 8.4 \\
\hline \multirow[t]{5}{*}{ with recycle } & 36 & 4.1 \\
\hline & 24 & 7.0 \\
\hline & 20 & 8.4 \\
\hline & 17 & 9.9 \\
\hline & 14 & 10.8 \\
\hline
\end{tabular}
volume of an internal standard containing $1000 \mathrm{mg} / \ell$ isobutyric acid. VFA concentrations were determined using the internal standard method described by Ackman (1972) using a HewlettPackard 5840A gas chromatograph and a Chromosorb 101 packed column (3048 $\mathrm{mm} \times 2 \mathrm{~mm} \mathrm{ID,} \mathrm{80/100} \mathrm{mesh} \mathrm{size).} \mathrm{The}$ flame ionisation detector was $350^{\circ} \mathrm{C}$, oven temperature $180^{\circ} \mathrm{C}$ and injection temperature of $250^{\circ} \mathrm{C}$. The flow rate of the formic acid saturated helium carrier gas was $15 \mathrm{~m} \ell / \mathrm{min}$.

\begin{tabular}{|l|c|}
\hline \multicolumn{2}{|c|}{ TABLE 2 } \\
Feed composition \\
\hline Component & Amount \\
\hline $\mathrm{ADF}$ & $10 \mathrm{~m} \ell / \ell$ \\
\hline $\mathrm{NH}_{4} \mathrm{HCO}_{3}$ & $1.6 \mathrm{~g} / \ell$ \\
\hline $\mathrm{NaHCO}_{3}$ & $3.63 \mathrm{~g} / \ell$ \\
\hline $\mathrm{KHCO}_{3}$ & $2.78 \mathrm{~g} / \ell$ \\
\hline$\left(\mathrm{NH}_{4}\right)_{2} \mathrm{SO}_{4}$ & $0.40 \mathrm{~g} / \ell$ \\
\hline $\mathrm{K}_{2} \mathrm{HPO}_{4}$ & $0.21 \mathrm{~g} / \ell$ \\
\hline $\mathrm{KH}_{2} \mathrm{PO}_{4}$ & $0.16 \mathrm{~g} / \ell$ \\
\hline Yeast extract & $0.08 \mathrm{~g} / \ell$ \\
\hline
\end{tabular}

TSS and VSS samples were determined using procedures outlined in Standard Methods (1985). Biomass samples were placed in a pre-ashed, pre-weighed crucible and dried in a $108^{\circ} \mathrm{C}$ oven overnight and the dry weight was recorded. The dry sample was then ashed in a $550^{\circ} \mathrm{C}$ muffled furnace for $20 \mathrm{~min}$. The difference between the dry mass and the crucible mass represented the TSS portion of the biomass, while the difference between the dry and ashed mass represented the VSS portion. Effluent samples were filtered through GF/C glass filters (VWR Canlab) and the filters were dried then ashed for TSS and VSS determination.

\section{Results}

Mixing tests were carried out at HRTs of $36 \mathrm{~h}, 6 \mathrm{~h}$ and $1 \mathrm{~h}$ using a step input of Rhodamine tracer to characterise the hydrodynamic mixing of the ABR in terms of CSTRs-in-series. F curves were created from the experimental RTD time-concentration data collected for HRTs of $36 \mathrm{~h}, 6 \mathrm{~h}$ and $1 \mathrm{~h}$. Figure 2 represents the mixing study carried out at HRT of $36 \mathrm{~h}$. Unitless concentration $\mathbf{F}$ is plotted against unit-less time $\theta$, and has superimposed upon it the theoretical models for $\mathrm{N}=4$ and $\mathrm{N}=5$ CSTRs-in-series. As can be seen from this figure, either model could describe the mixing within the ABR under these conditions. Similar comparisons were carried out for the $6 \mathrm{~h}$ and $1 \mathrm{~h}$ HRT mixing tests.

Table 3 summarises the $\mathrm{R}^{2}$ values for each of these RTD studies and shows that although the $\mathrm{N}=5$ model provides a slightly better fit than the $\mathrm{N}=4$ model (1.02 vs. 0.94 at $36 \mathrm{~h}$ HRT; 1.01 vs. 0.93 at $6 \mathrm{~h} \mathrm{HRT}$; and 0.92 vs. 0.85 at $1 \mathrm{~h} \mathrm{HRT)} \mathrm{it}$ is never implausible that $\mathrm{N}=4$. Additionally, it is reasonable to use $\mathrm{N}=4$, since this is the actual number of ABR compartments. Furthermore, although residual plots for the $\mathbf{F}$ curve model show some deviation from the data at $\theta$ less than 1 , at $\theta$ greater than 1 , the model fit was adequate. Therefore, it was reasonable to assume that hydrodynamically the experimental ABR may be represented as 4-CSTRs-in-series. 


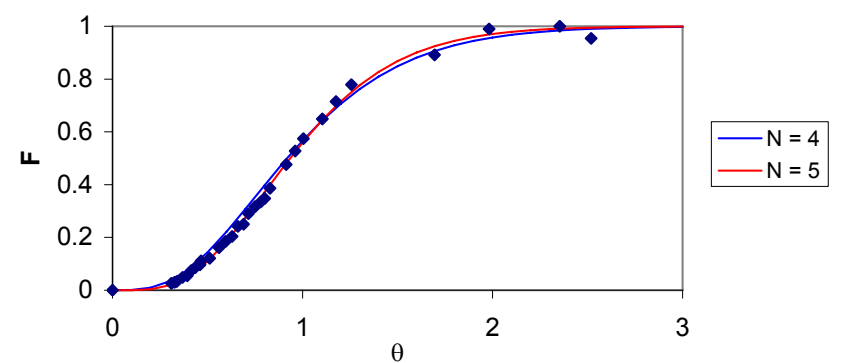

Figure 2

F curve for 36 h HRT with $N=4$ and 5 models superimposed

\begin{tabular}{|l|c|c|c|}
\hline \multicolumn{4}{|c|}{ TABLE 3 } \\
Comparison of model fits for mixing tests \\
\hline & \multicolumn{3}{|c|}{$\mathbf{R}^{\mathbf{2}}$} \\
\hline F curve model & $36 \mathrm{~h}$ HRT & $6 \mathrm{~h} \mathrm{HRT}$ & $1 \mathrm{~h} \mathrm{HRT}$ \\
\hline $\mathrm{N}=4$ & 0.94 & 0.93 & 0.85 \\
\hline $\mathrm{N}=5$ & 1.02 & 1.01 & 0.92 \\
\hline
\end{tabular}

These results agree with those of Grobicki and Stuckey (1992) who concluded that reactors operated with biomass and gas-mixing were even better suited for CSTR-in-series characterisation. They reported that under operating conditions mixing improved and that the number of theoretical compartments was equal to the actual number of reactor compartments and that increased mixing caused by the evolution of biogas compensated for the presence of biological dead space. Given the results of the mixing study and in consideration of the results reported by Grobicki and Stuckey (1992) it was reasonable to assume that the ABRs in this study could be represented by 4-CSTRs-in-series where a single sample would be representative of the soluble concentration within an entire compartment.

\section{Biological treatment of ADF}

Two $28.4 \ell$ ABRs (with and without recycle) were operated for a period of about 6 months at various SS conditions with acclimated sludge. Finally, the ABRs were shut down for three months and left at $35^{\circ} \mathrm{C}$ in order to determine whether they could be restarted. Upon re-start the ABRs were brought back to preshut down HRT and COD removal efficiencies within $3 \mathrm{~d}$ after re-start which is ideal for seasonal ADF operations.

Since mixing studies indicated that the ABR behaved as 4-CSTR-in-series, SS compartment to compartment COD profiles were created to follow the change in COD as substrate moved through the ABRs. In the case of the ABR with recycle, the effluent from Compartment 4 was also the portion of the reactor contents that was recycled back to the inlet and therefore affected the concentration of the liquid entering into Compartment 1. When the ABR was operated without recycle (Fig. 3), the COD concentration decreased steadily as the wastewater moved through the reactor, from Compartment 1 to Compartment 4 for each HRT tested. For example, at an HRT of $27 \mathrm{~h}$, influent COD of $7000 \mathrm{mg} / \ell$, decreased to 5500,3600 , 1700 , and $700 \mathrm{mgCOD} / \ell$ at the outlets of Compartments $1,2,3$ and 4 respectively. It is also important to note that, as the HRT decreased (OLR increased), COD concentrations within each compartment increased accordingly. For example, in Compartment $1 \mathrm{COD}$ concentrations increased from $2000 \mathrm{mg} / \ell$ at an HRT of $39 \mathrm{~h}$ to $5500 \mathrm{mg} / \ell$ at an HRT of $27 \mathrm{~h}$ and finally to $6500 \mathrm{mg} / \ell$ at an HRT of $20 \mathrm{~h}$. This same trend occurred in each compartment with decreasing HRT.

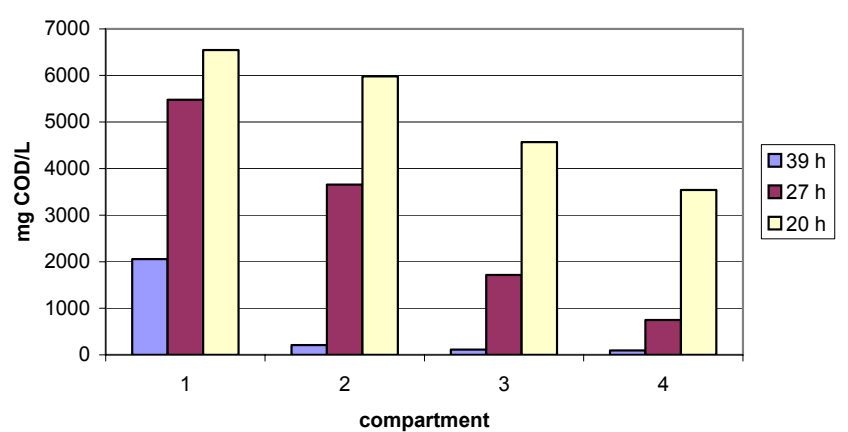

Figure 3

HRT vs COD profile, no recycle

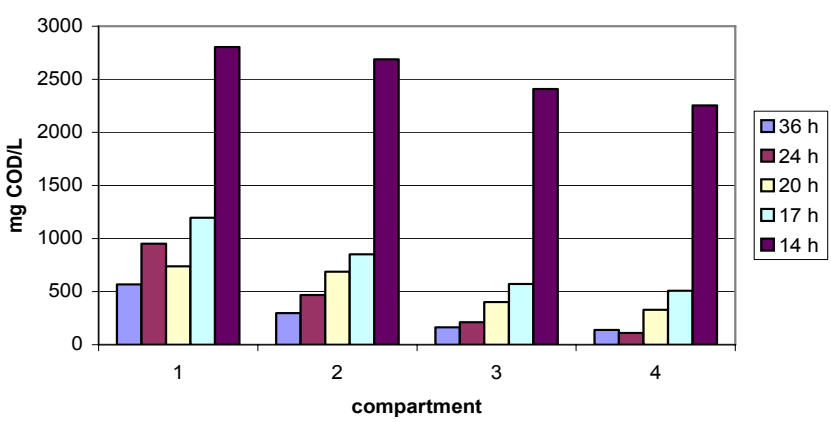

Figure 4

HRT vs COD profile, with recycle

For ABR operated with recycle (Fig. 4), the same phenomenon was also observed, but to a lesser degree. For example, at an HRT of $24 \mathrm{~h}$, the COD in each compartment of the ABR with recycle decreased from the $1000 \mathrm{mg} / \ell$ in Compartment 1 to $100 \mathrm{mg} / \ell$ in Compartment 4 , an overall decrease by a factor of 10. In contrast, in the ABR without recycle at an HRT of $27 \mathrm{~h}$ the decrease between Compartments 1 and 4 was by a factor of about 8 . While the CODs decreased by about the same factor in both cases, the effluent COD concentration was much higher in the ABR without recycle indicating improved performance with recycle. What is also visible from these two figures is that for all HRTs evaluated, the COD concentration in Compartment 1 as well as for all subsequent compartments was always lower for the ABR operated with recycle than for the ABR operated without recycle at similar HRTs. This is the recycle dilution effect. The low COD out of the $4^{\text {th }}$ compartment acted to dilute the relatively high COD of the feed wastewater at the 6:1 recycle to feed ratio used in the study.

Compartment to compartment COD removal efficiency profiles are more useful to describe ABR operation. Since each compartment operates as a CSTR, COD removal efficiency can be calculated from Eq. (5):

$$
\% \text { COD removed }=\frac{\mathrm{COD}_{\text {in }}-\mathrm{COD}_{\text {out }}}{\mathrm{COD}_{\text {in }}} \times 100 \%
$$

where:

$\mathrm{COD}_{\text {in }}$ and $\mathrm{COD}_{\text {out }}$ are the COD concentrations into and out of each compartment.

Figure 5 shows overall (cumulative COD removal) as well as compartment to compartment COD removal efficiency versus HRT for the ABR without recycle. Without recycle, overall COD removal efficiency at the longest HRT of $39 \mathrm{~h}$ was $98.7 \%$ with most of the COD removed in Compartment 1 (71\%) and 26\% in Compartment 2. Less than $2 \%$ of the overall COD was removed 
in Compartments 3 and 4 which indicated that the entire reactor volume was not being utilised to its full potential. Because of the high COD removal in Compartments 1 and 2, both the specific loading rate $(\mathrm{g} \mathrm{COD} / \mathrm{g}$ biomass $\cdot \mathrm{d})$ and substrate concentration driving force in the latter Compartments (3 and 4) were low resulting in a lower substrate utilisation rate. Similar results were reported by Xing et al. (1991) who reported that up to $80 \%$ of the total COD removal occurred within Compartment 1 under particular operating conditions.

VFA profiles indicated that the ABR naturally selected for biological phase separation. At $39 \mathrm{~h}$ HRT, the acidification of the feed in the first compartment was significant with an acetic acid concentration greater than $1500 \mathrm{mg} / \ell$ (Fig. 6a). Butyric acid was also present at a lower concentration $(270 \mathrm{mg} / \ell)$ but was consumed in Compartment 2. VFA concentrations in Compartments 2 to 4 were negligible. This is in accordance with the COD consumption that occurred primarily in the $1^{\text {st }}$ and $2^{\text {nd }}$ compartments. These results suggest that acidogenesis and methanogenesis occurred simultaneously within the first compartment and the remaining acids produced in the first compartment were consumed by methanogenic bacteria in the second compartment.

At an HRT of $27 \mathrm{~h}$ the ABR without recycle obtained an acceptable COD removal efficiency of $89 \%$ at an OLR of $6.2 \mathrm{~g}$ $\mathrm{COD} / \ell_{\text {reactor }} \cdot \mathrm{d}$. This corresponded to an SOLR of $0.30 \mathrm{~g} \mathrm{COD} /$ $\mathrm{g}$ VSS·d and SORR of $0.25 \mathrm{~g} \mathrm{COD}_{\text {rem }} / \mathrm{g} \mathrm{VSS} \cdot \mathrm{d}$. As the reactor operated at shorter HRT, down to a $27 \mathrm{~h}$ HRT, Fig. 5 shows that the COD removal was equally distributed across all four ABR compartments. This indicates that as the load was increased and ABR was stressed, the latter compartments played a greater role in terms of COD removal.

At $27 \mathrm{~h}$ HRT, acetic acid concentrations rose from the first to the second compartment indicating that acidification had moved through the reactor, occurring not only in the first compartment as in the $39 \mathrm{~h}$ HRT (Fig. 6b). Also, the rising concentrations of butyric acid indicated that the anaerobic microbial consortia were beginning to be stressed (Speece, 1996). The overall acid concentrations in the reactor effluent were still slightly less than $1000 \mathrm{mg} / \ell$.

At the shortest HRT tested (20 h) (Fig. 5), it can be seen that the ABR was operating at an overall COD removal efficiency of about $50 \%$, which was below the $70 \%$ overall COD removal which was deemed to be the cut off point for acceptable COD removal. For this reason, the series of SSs was halted at this point. In this case, Compartments 3 and 4 accounted for most of the COD removal ( $37 \%$ overall removal) while Compartments 1 and 2 accounted for about $13 \%$ COD removal. The decreased removal in Compartments 1 and 2 suggests that for these conditions acidogenesis was predominating (no COD removal during acidogenesis) and that a more balanced methanogenic anaerobic consortium occurred mainly in the final two compartments. This was verified by the ABR VFA profiles which increased in all compartments to between 2000 to $2700 \mathrm{mg} / \ell$ and accounted for most of the COD in the effluent. Butyric acid concentrations

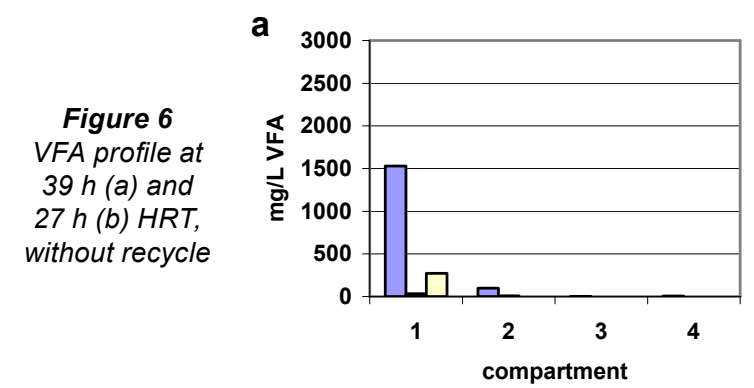

were above $500 \mathrm{mg} / \ell$ in three of the four compartments indicating increased stress on the methanogenic biomass in those compartments (Speece, 1996). It should be noted that although the acid concentrations increased within the ABR, due to buffering the $\mathrm{pH}$ within the reactors remained at $7.0 \pm 0.2$. Therefore, although $\mathrm{pH}$ is known to play a major role in reactor souring, the mere presence of the acids in a $\mathrm{pH}$ buffered solution inhibits methanogenesis.

The definition of COD removal efficiency within each compartment for the ABR operated with recycle must be re-evaluated in order to avoid an artificially high COD removal within Compartment 1 due to the recycle dilution effect. The main ramification of this redefinition is that the COD concentration into the first is COD concentration of the feed diluted by the recycle COD concentration. Using the above definition, compartmental COD removal expressed as percentages of the overall removal can now be more closely examined to compare performance at different HRTs. COD removal efficiency remained greater than $90 \%$ for all SS conditions down to an HRT of $17 \mathrm{~h}$ (Fig. 7). At an HRT of $14 \mathrm{~h}$ COD removal efficiency dropped to about $62 \%$ below the acceptability limit of $70 \%$. However it was clear that recycle resulted in improved ADF treatment at a shorter HRT $(17 \mathrm{~h})$ and greater OLR than for the ABR without recycle (HRT $27 \mathrm{~h}$ ).

On the compartmental level with recycle (Fig. 7), at the longest HRT (36 h) Compartment 1 accounted for $47 \%$ of the total COD removed while each successive compartment removed a smaller fraction of their influent COD (33\% in Compartment 2, $17 \%$ in Compartment 3 and $3 \%$ in Compartment 4.) This was expected since as the COD concentration decreased in the preceding compartment the resultant COD driving force in the subsequent compartment was reduced, leading to a lower removal efficiency. Compartmental VFA profiles for an HRT of $36 \mathrm{~h}$ were $<400,<200,50$ and $<50 \mathrm{mg} / \ell$ for Compartments $1,2,3$ and 4 respectively.

As HRT decreased from $36 \mathrm{~h}$ to $24 \mathrm{~h}$, and $17 \mathrm{~h}$ COD removal efficiency within the first compartment diminished and subsequent compartments showed greater compartmental removal efficiencies (Fig. 7). At the $24 \mathrm{~h}$ HRT SS condition it can be seen

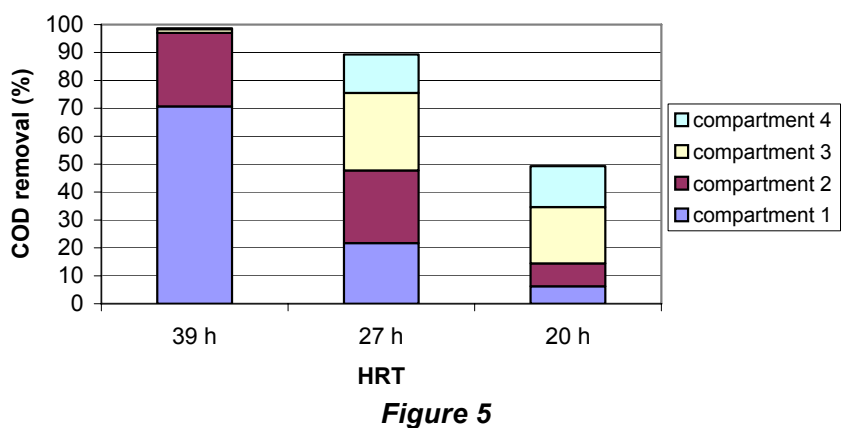

COD removal efficiency at the outlet of each compartment no recycle

b

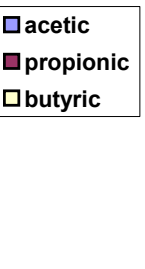

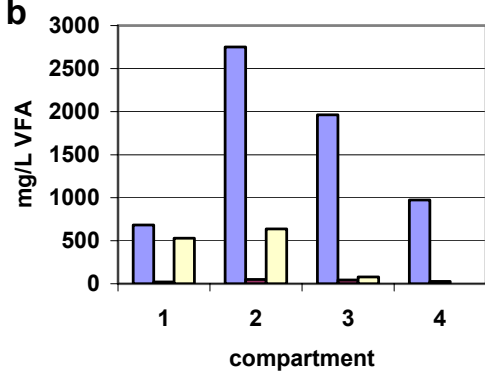

$\square$ acetic

$\square$ propionic

口butyric 


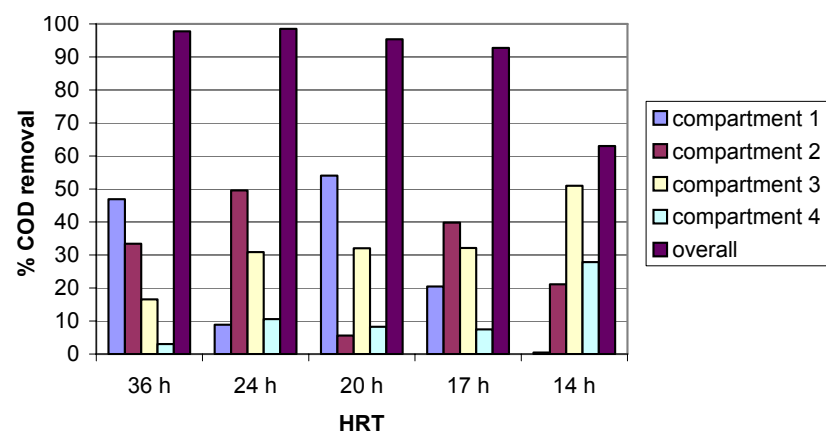

Figure 7

COD removal with recycle where compartmental removals are in percentages of overall removal accounting for dilution

that significant COD removal occurred in the latter three reactor compartments. Compartment 1 accounted for only $9 \%$ of the total COD removal while the second compartment accounted for $50 \%$, the third compartment accounted for $31 \%$, and the last compartment accounted for $11 \%$ of the total COD removal. Again data indicates that in the ABR a natural biological phase separation occurs. The first compartment acted as an acidogenic phase reactor, consequently the second compartment selected for a microbial consortium that stabilised the COD. Similar results were observed at shorter HRTs down to 17h. VFA profiles for 24 $\mathrm{h}$ and $17 \mathrm{~h}$ HRT which were typical of the shorter HRTs (Figs. 8a and b) support this hypothesis. At $24 \mathrm{~h}$ HRT the acetic acid concentration in compartment one had risen to above $600 \mathrm{mg} / \ell$ with a butyric acid concentration of about $50 \mathrm{mg} / \ell$. The acetic acid concentrations decreased by about $50 \%$ and butyric concentrations were no longer detectable at the outlet of Compartment 2. At 17h HRT the VFA profile indicates that the levels of biomass stress within the reactor were increasing. In particular, the first compartment was showing significant concentrations of butyric acid, which was not completely stabilised until it exited the third compartment. Additionally, the acetic acid concentration exiting the reactor was about $300 \mathrm{mg} / \ell$. It must be noted that as the outlet acid concentrations increased (with the concurrent COD increase) the amount of acids returned to the inlet via the recycle increased. Therefore the increased acid concentrations in the first compartment was not entirely due to an increase in acidogenic activity, but was due in part to the recycled acid from the last compartment.

With recycle the ABR achieved a minimum HRT of $17 \mathrm{~h}$ with an acceptable COD removal efficiency of $93 \%$ at an OLR of $9.9 \mathrm{~g} \mathrm{COD} / \ell_{\text {reactor }} \cdot \mathrm{d}$. This corresponded to SOLR of $0.35 \mathrm{~g} \mathrm{COD} /$ $\mathrm{g}$ VSS $\mathrm{d}$ and SORR of $0.32 \mathrm{~g} \mathrm{COD} \mathrm{rem}_{\mathrm{r}} / \mathrm{g}$ VSS·d. Additionally, at the $17 \mathrm{~h}$ HRT SS condition an increased proportion of COD removal was associated with the latter ABR compartments. The first compartment accounted for $20 \%$ of the overall removal while the second, third and fourth compartments accounted for $40 \%, 32 \%$ and $8 \%$ of the total removal respectively.
As mentioned previously, when the reactor was operated at a $14 \mathrm{~h} \mathrm{HRT}$, the overall COD removal efficiency dropped to $63 \%$, which was below the acceptable removal level (Fig. 7). There was an increase in COD concentration from the first to the second compartment but this increase was well within the error associated with the measurements, leading to a net $0 \%$ COD removal efficiency in the first compartment. Fifty per cent of total COD removal occurred within the third compartment with the $2^{\text {nd }}$ and $4^{\text {th }}$ compartments accounting for 21 and $28 \%$ of total COD removal respectively. Overall, the majority of COD removal had shifted from the first compartment at $36 \mathrm{~h}$ HRT to the second compartment at $24 \mathrm{~h}$ and $17 \mathrm{~h}$ HRT to the third compartment at a $14 \mathrm{~h}$ HRT. The VFA profile from compartment to compartment was constant for the 14h HRT SS condition with acetic propionic and butyric acid concentrations of 1600,150 and $300 \mathrm{mg} / \ell$ in all compartments.

Using COD equivalences, it was possible to determine what portion of the COD could be attributed to the VFA and in this way determine how far into the reactor the substrate had penetrated before being acidified. For the ABR operated with recycle all the COD seen at the outlet of each of the compartments for all HRTs studied was due to VFAs and none due to the original ADF substrate as all the substrate was acidified within the first compartment. Without recycle, ADF substrate was acidified in Compartment 1 at a $39 \mathrm{~h}$ HRT while ADF substrate accounted for $69 \%$ of the COD out of Compartment 1 at an HRT of $27 \mathrm{~h}$. At the final HRT of $20 \mathrm{~h}$, the ADF substrate accounted for $90 \%$ of the COD out of Compartment $1,40 \%$ of the COD out of Compartment 2 and $30 \%$ out of Compartments 3 and 4 . This indicates that for the ABR operated without recycle insufficient acidogenesis occurred and the decrease in COD removal was not due solely to insufficient methanogenesis as was the case in the ABR operated with recycle.

Biogas quality and quantity were measured periodically through the experimental period. The biogas quality was found to be $60 \pm 2 \%$ methane with a methane production of $0.32 \pm 0.02$ $\ell \mathrm{CH}_{4} / \mathrm{g} \mathrm{COD}_{\mathrm{rem}}$, which although less than the theoretical methane potential of $0.35 \ell \mathrm{CH}_{4} / \mathrm{g} \mathrm{COD}_{\mathrm{rem}}$ at STP (Speece, 1996) is not significantly different. The close correlation between COD removal based on COD analysis and biogas measurements gives considerable confidence to the results.

\section{Biomass accumulation and characteristics}

In high-rate reactors such as ABRs, maximum loading rates are partly limited by the rate of loss or accumulation of granular biomass. Throughout the test volatile solids density within the granular biomass remained constant at $0.043 \pm 0.0005 \mathrm{~g} \mathrm{VSS} / \mathrm{m} \ell$ while the fraction of volatile to total solids remained constant at $0.74 \pm 0.002 \mathrm{~g} \mathrm{VSS} / \mathrm{g}$ TSS for both reactors.

Figure 9 indicates a net positive biomass yield in both the ABRs operated with and without recycle. From the initial $430 \mathrm{~g}$ VSS inoculum ( $10 \ell$ at $43 \mathrm{~g}$ VSS/ $\ell$ ) biomass increased steadily a

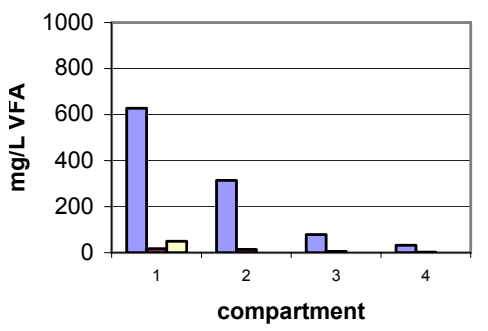

b

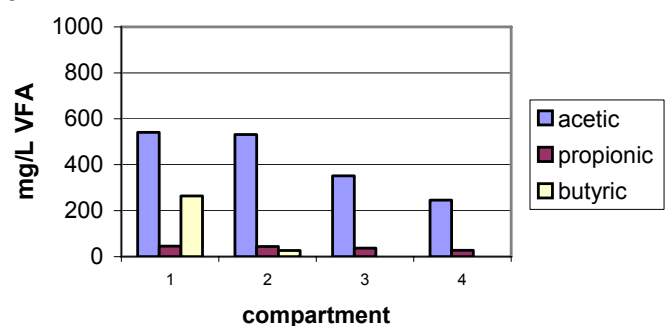

Figure 8

VFA profile at $24 h$ (a) and $17 \mathrm{~h}$ (b) $H R T$, with recycle 
Figure 9

Biomass inventory across the reactor without

(a) and with (b) recycle

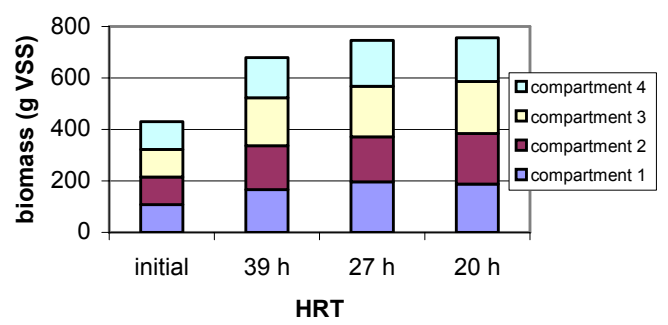

b

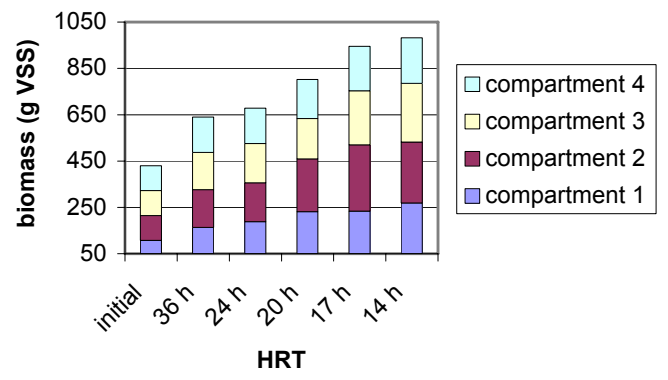

through both ABRs more or less evenly through the compartments. Without and with recycle the final mass of biomass in the reactor was $756 \mathrm{~g}$ VSS and $983 \mathrm{~g}$ VSS, respectively. Visually it was observed that hydraulic effects in an ABR cause the biomass to be preferentially distributed within the upflow section of each compartment. This is advantageous since the partial fluidisation of the biomass within the upflow sections increases the availability of the substrate to the granular biomass.

In the ABR without recycle, the overall biomass yield was found to be $0.015 \mathrm{~g} \mathrm{VSS} / \mathrm{g} \mathrm{COD}_{\text {rem }}$ while the overall yield for the ABR operated with recycle was found to be of $0.022 \mathrm{~g} \mathrm{VSS} / \mathrm{g}$ $\mathrm{COD}_{\text {rem. }}$. The greater overall yield noted in the ABR operated with recycle may be attributed to lower levels of stress within the reactor due to lower VFA concentrations. In previous tests (Pham, 2002) with similar anaerobic granules treating $1.2 \%$ $\mathrm{ADF}(\mathrm{COD}=8400 \mathrm{mg} / \ell)$ the yield was found to be of 0.027 $\mathrm{g} / \mathrm{g}$ COD therefore the overall biomass yield in the ABR is in agreement with previously reported results. More important than overall yield is the net accumulated yield of biomass. A large biomass yield with a negative accumulation of biomass in the reactor would lead to washout. The net accumulated yield within the ABR was found to be $0.007 \mathrm{~g} \mathrm{VSS} / \mathrm{g} \mathrm{COD}$ rem and $0.016 \mathrm{~g} \mathrm{VSS} / \mathrm{g} \mathrm{COD}_{\text {rem }}$ without and with recycles respectively. The ABR operated without recycle retained $50 \%$ of the biomass yield whereas the ABR operated with recycle retained $70 \%$ of the biomass yield. The greater percentage and amount of biomass retained within the ABR with recycle may be attributed to better mixing. The increased mixing with recycle may have served to promote detachment of gas bubbles from anaerobic granules, thereby preventing washout and increasing SRT.

Settling characteristics of ABR biomass for initial inoculum and granular biomass from each of the compartments at the end of the experimental campaign were compared and in all cases typical S- type settling curves were obtained. To facilitate comparison of different biomass samples, the settling velocity for the granular biomass, $v_{50}$, is considered to be the velocity at which $50 \%$ of the biomass has washed out. The average $v_{50}$ for the initial biomass was $49 \pm 7 \mathrm{~m} / \mathrm{h}$ while at the end of the experimental period for each compartment of the ABR with and without recycle, were found to have $v_{50}$ of $50 \pm 5 \mathrm{~m} / \mathrm{h}$ and, $47 \pm 2 \mathrm{~m} / \mathrm{h}$ respectively. In effect, no significant change in settling velocity was noted and all variations within the settling tests were well within the error associated with the test. Contrary to the evolutionary settling characteristics for UASB reactors found by Pham (2002), the settling characteristics of the biomass within the $\mathrm{ABR}$ with and without recycle remained constant throughout the experimental period; concomitantly settling characteristics could not be correlated to the rate of washout of biomass. The only appreciable change in the quality of the biomass was that the biomass colour was originally a uniform black colour, but with time the colouration lightened to a lighter brown. This was first noted in Compartment lof the ABR operated with recycle and gradually spread from the first to the second compartment.

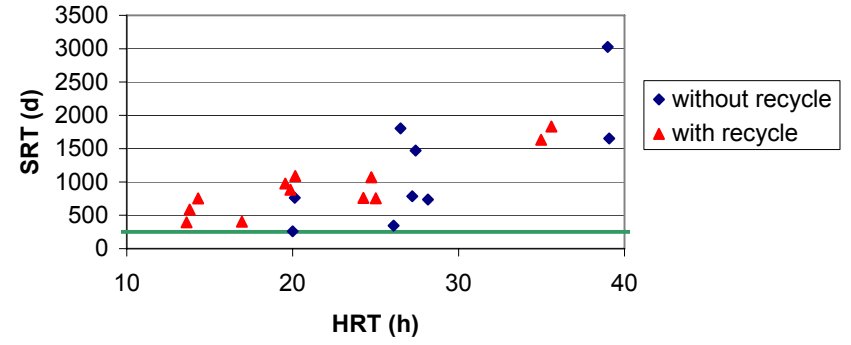

Figure 10

$S R T$ variation with HRT, with and without recycle

This phenomenon was also observed by Hutňan et al. (1999) who attributed it to a shift within the granule to a predomination of acidogenic and hydrolytic bacteria. A predominance of acidogenic bacteria would agree with the compartmental VFA profiles which showed a rapid conversion of the substrate ADF to acetic acid in Compartments 1 and 2 .

It should be noted that although biomass yields were within established ranges for mesophilic anaerobic yields, they are also very low. Although this is good for sludge management, any upset that resulted in biomass washout would require a great deal of time to recover from biomass losses. For UASB reactors treating ADF the SRT was the limiting factor in treatment rates. In ABR treatment of ADF however this was not the case. Figure 10 shows SRT remained above $250 \mathrm{~d}$ for all HRTs even after COD removal efficiencies had dropped below the $70 \%$ acceptability limit (minimum SRT of $260 \mathrm{~d}$ for $20 \mathrm{~h}$ HRT without recycle and a minimum SRT of $400 \mathrm{~d}$ for $14 \mathrm{~h}$ HRT with recycle.). The horizontal line in Fig. 10 represents an SRT of 250 d, which is 10 to 15 times greater than the SRT used in conventional anaerobic treatment system design. It is evident that in an ABR treating $\mathrm{ADF}$ at an HRT ranging between $39 \mathrm{~h}$ and $20 \mathrm{~h}$ without recycle and between $36 \mathrm{~h}$ and $14 \mathrm{~h}$ with recycle, the success of treatment is independent of SRT and in fact a method of biomass wastage would become necessary if a constant biomass concentration within the ABR were desired. The long SRT and positive biomass accumulation characteristics of the ABR suggest that eventually lower specific loading rates and successful application at shorter HRTs and more dilute ADF may be possible.

\section{Conclusions}

A $1 \% \mathrm{v} / \mathrm{v}(7000 \mathrm{mg} \mathrm{COD} / \ell)$ ADF wastewater was successfully treated in ABRs operated with and without recycle at OLRs varying between 4 and $11 \mathrm{~g} \mathrm{COD} / \ell_{\text {reactor }} \cdot d$. The ABR operated without recycle achieved a minimum HRT of $27 \mathrm{~h}$ with an acceptable COD removal efficiency of $89 \%$. This corresponded to an OLR of $6.2 \mathrm{~g} \mathrm{COD} / \ell_{\text {reactor }} \cdot \mathrm{d}$, a SOLR of $0.30 \mathrm{~g} \mathrm{COD} / \mathrm{g} \mathrm{VSS} \cdot \mathrm{d}$ and a SORR of $0.25 \mathrm{~g} \mathrm{COD}_{\text {rem }} / \mathrm{g} \mathrm{VSS} \cdot \mathrm{d}$. The ABR operated with a $6: 1$ recycle ratio achieved a minimum HRT of $17 \mathrm{~h}$ with an acceptable COD removal efficiency of $93 \%$ at an OLR of $9.9 \mathrm{~g} \mathrm{COD} / \ell_{\text {reactor }} \cdot \mathrm{d}$, SOLR of $0.35 \mathrm{~g} \mathrm{COD} / \mathrm{g} \mathrm{VSS} \cdot \mathrm{d}$ and SORR 
of $0.32 \mathrm{~g} \mathrm{COD} / \mathrm{g}$ VSS $\cdot \mathrm{d}$. Due to biomass growth SOLR were not found to vary significantly through most of the experimental period despite OLR increases. It was also found that ABR treating ADF may be shut down for a period of months and then restarted with ease.

Hydrodynamically, ABR may be characterised as CSTR-inseries where the number of CSTRs corresponded to the number of actual compartments. VFA profiles tend to indicate that ABR compartmentalisation serve to separate acidogenic and methanogenic activities longitudinally through the reactor, with the highest proportion of acidogenic activity in the first compartments.

Biomass settling characteristics were found to remain constant with and without recycle at about $49 \mathrm{~m} / \mathrm{h}$. This allowed both ABR to achieve SRTs in excess of $250 \mathrm{~d}$ for the range of HRT studied. Since there was a net positive biomass yield, biomass wastage would become necessary if a constant SRT were desired. The net accumulated yield within the ABR was found to be $0.007 \mathrm{~g} \mathrm{VSS} / \mathrm{g} \mathrm{COD}$ when the ABR was operated without recycle and $0.016 \mathrm{~g} \mathrm{VSS} / \mathrm{g} \mathrm{COD}_{\text {rem }}$ for the ABR operated with recycle.

\section{References}

ACKMAN RG (1972) Porous polymer bead packing and formic acid vapour in GLC of volatile fatty acids. J. Chromatogr. Sci. $10560-$ 565.

ANDRAS E, KENNEDY KJ and RICHARDSON DA (1989) Test for characterizing settleability of anaerobic sludge. Environ. Tech. Lett. 10 463-470.

BACHMANN A, BEARD VL and McCARTY PL (1983) Comparison of fixed film reactors with a modified sludge blanket reactor. In: YC Wu and ED Smith (eds.). Fixed Film Biological Processes for Wastewater Treatment. Noyes Data, NJ.

BACHMANN A, BEARD VL and McCARTY PL (1985) Performance characteristics of the anaerobic baffled reactor. Water Res. 19(1) 99106.

BARBER WP and STUCKEY DC (1999) The use of the anaerobic baffled reactor (ABR) for wastewater treatment: a review. Water Res. 33 (7) 1559-1578.

BOOPATHY R and TILCHE A (1991) Anaerobic digestion of high strength molasses wastewater using hybrid anaerobic baffled reactor. Water Res. 25 (7) 785-790.
CHYNOWETH DP, SRIVASTRA VJ and CONRAD JR (1980) Research Study to Determine the Feasibility of Producing Methane Gas from Sea Kelp. Annual Report for General Electric Company, IGT Project 20502. Institute of Gas Technology, IIT Centre, $3424 \mathrm{~S}$. State Street, Chicago, IL 60616.

DARLINGTON C and KENNEDY KJ (1998) Biodegradation of aircraft de-icing fluid in an upflow anaerobic sludge blanket (UASB) reactor. J. Environ. Sci. Health. A33 (3) 339-351.

GROBICKI A and STUCKEY DC (1991) Performance of the anaerobic baffled reactor under steady-state and shock loading conditions. Biotechnol. Bioeng. 37 344-355.

GROBICKI A and STUCKEY DC (1992) Hydrodynamic characteristics of the anaerobic baffled reactor. Water Res. 26 (3) 371-378.

HENZE M and HARREMOËS P (1983) Anaerobic treatment of wastewater in fixed film reactors: A literature review. Water Sci. Technol. 15 (8-9) 1-101.

HUTNAN M, MRAFKOVÁ L, DRTIL M and DERCO J (1999) Methanogenic and nonmethanogenic activity of granulated sludge in anaerobic baffled reactor. Chem. Papers. 53 (6) 374-378.

LEVENSPIEL O (1999) Chemical Reaction Engineering ( $3^{\text {rd }}$ edn.). John Wiley \& Sons, New York.

MULLIGAN CJ, CHEBIB J and SAFI B (1997) Anaerobic Treatment of Aircraft De-Icing Agent Using the SNC-Lavalin Multiplate Reactor. AWMA's $90^{\text {th }}$ Annual Meeting \& Exhibition, June 8-13, Toronto, Ontario, Canada.

NACHAIYASIT S (1995) Effect of Process Parameters on Reactor Performance in an Anaerobic Baffled Reactor. Ph.D. Dissertation, Dept of Chemical Engineering, Imperial College, London, U.K.

PHAM T (2002) Anaerobic Degradation of Aircraft De-Icing Fluid (ADF) in Upflow Anaerobic Sludge Blanket Reactors and Fate of ADF Additives. Ph.D. Dissertation, Dept of Chemical Engineering, University of Ottawa, Ottawa, ON.

SPEECE RE (1996) Anaerobic Biotechnology for Industrial Wastewaters. Archae Press, Nashville, TN.

SWITZENBAUM MS, VELTMAN S, MERICAS D, WAGONER B and SCHOENBERG T (2001) Best management practices for airport stormwater. Chemosphere 43 1051-1062.

STANDARD METHODS (1985) Standard Methods for the Examination of Water and Wastewater $\left(16^{\text {th }}\right.$ edn.). American Public Health Association (APHA), Washington, D.C.

TILCHE A and YANG X (1987) Light and scanning electron microscope observations on the granular biomass of experimental SBAF and HABR reactors. Proc. Gasmat Workshop, Netherlands. 170178

XING J, BOOPATHY R and TILCHE A (1991) Model evaluation of hybrid anaerobic baffled reactor treating molasses wastewater. Biomass Bioenerg. 1 (5) 267-274. 